\title{
Study on the genus Rhopobota Lederer from China (Lepidoptera: Tortricidae: Olethreutinae)
}

\author{
Aihuan Zhang, Houhun Li* \& Shuxia Wang
}

Zhang, A., Li, H. \& Wang, S. 2005: Study on the genus Rhopobota Lederer from China (Lepidoptera: Tortricidae: Olethreutinae). — Entomol. Fennica 16: 273286.

This paper deals with seventeen species of the genus Rhopobota from China. Five species ( $R$. furcata sp. n., R. orbiculata sp. n., R. fanjingensis sp. n., $R$. floccosa sp. n. and $R$. bucera sp. n.) are described as new to science and four species [R. blanditana (Kuznetsov), R. falcata Nasu, R. okui Nasu and R. symbolias (Meyrick)] are new for China. The male of Rhopobota eclipticodes (Meyrick) is described for the first time. Photographs of the adults and genitalia of the species mentioned are provided. A key to the known Chinese species is given based on adults and male genitalia.

A. Zhang, H. Li \& S. Wang, College of Life Sciences, Nankai University, Tianjin 300071, P. R. China; correspondent author'se-mail:lihouhun@nankai.edu.cn

Received 3 July 2004, accepted 7 March 2005

\section{Introduction}

The genus Rhopobota has faced several important taxonomic changes since mid-1800s, and the process has still continued until recently. Lederer (1859) erected Rhopobota for Tortrix naevana Hübner [1817]. More recently three genera, viz. Erinaea Meyrick, Norma Heinrich and Kundrya Heinrich, were synonymized with Rhopobota Lederer by Brown (1979). Brown (1983) also sunk Eumarissa Clarke to Rhopobota, transferred eight species from Griselda Heinrich to the present genus and listed 26 species in the world. Razowski (1999a) listed 15 Palaearctic species. Later Razowski (1999b) described four neotropical species, listed 34 species in the zoogeographic units and discussed the distribution of the genus.

Up to date, 43 species and subspecies have been recorded, eight of which have been reported to occur in China (Brown 1983, Razowski 1999a, 1999b, Nasu 1999, 2000). In the present paper, five new species are described, four species are presented as new to China, and the male of Rhopobota eclipticodes (Meyrick, 1935) is described for the first time.

The new species described in this paper are ordered at random, while the new records and other species are ordered alphabetically. The key provided here is artificial and just a tool for identification. It does not show the phylogenetic relations.

The type specimens are deposited in the Insect Collection, College of Life Sciences, Nankai University, Tianjin, P. R. China. Abbreviations used: MGAB (Muzeul de Istorie Naturala, "Grigore Antipa", Bucuresti, Romania); USNM (United States National Museum of Natural History, Washington, D. C., USA).

\section{Material and methods}

The study is based on examination of the specimens collected in the field by light trap and the 
photographs of the type materials of two species respectively deposited in USNM and MGAB. Genitalia were prepared following the methods described by Li \& Zheng (1996).

\section{Results}

\subsection{Rhopobota Lederer, 1859}

Rhopobota Lederer, 1859: 366. Type species: [Tortrix] naevana Hübner, [1817].

Erinaea Meyrick, 1907: 141. Type species: Erinaea chlorantha Meyrick, 1907.

Norma Heinrich, 1923: 191. Type species: Epinotia dietziana Kearfott, 1907.

Kundrya Heinrich, 1923: 192. Type species: Kundrya finitimana Heinrich, 1923.

Eumarissa Clarke, 1976: 39. Type species: Eumarissa leucognoma Clarke, 1976.

Distribution. Holarctic, Oriental, Australian and Neotropical regions.

Remarks. The characters of Rhopobota are variable, which are proved by our study again. Two characters, namely, the presence of lateral tegumentary projections of the tegumen in the male genitalia and the sclerotized band at caudal end of the corpus bursae in the female genitalia, have however been considered as synapomorphies for the genus (Brown, 1983; Razowski, 1989).

The species of Rhopobota have a sclerotized band at the caudal end of the corpus bursae, which is also found in the female genitalia of Nuntiella Kuznetsov (Zhang \& Li, 2004). There is, however, no evidence that these similarities are synapomorphic.

\subsection{Key to the Chinese species of Rhopobota based on adults and male genitalia}

1. Socii long, large finger-shaped

- Socii small, triangular or of other shape 10

2. Tegumentary projections small, not produced into boot shape or sickle shape apically; cucullus distinctly dilated

- Tegumentary projections narrow and long, boot-shaped or sickle-shaped apically; cucullus slightly dilated
3. Sacculus with a finger-shaped process on ventral edge of basal opening

- Sacculus without such process on ventral edge of basal opening

6

4. Fore wing upperside ground color bicolored, viz., the anterior part blackish brown and the posterior part pale greyish brown

R. bicolor Kawabe

- Fore wing upperside without characters mentioned above

5. Hind wing upperside with a blue blotch on costa

R. naevana (Hübner)

- Hind wing upperside without such blotch on costa R. latipennis (Walsingham)

6. Sacculus with ventral angle obtuse R. symbolias (Meyrick)

- Sacculus with ventral angle indistinct

R. falcata Nasu

7. Sacculus with a semicircular or papillary process at base

- Sacculus without such process at base 9

8. Cucullus rounded dorsally, with two long setae on outer margin

R. okui Nasu

- Cucullus straight dorsally, with three or four long setae on outer margin

$$
\text { R. eclipticodes (Meyrick) }
$$

9. Sacculus with a large process on ventral edge of basal opening, reaching costa

R. ustomaculana (Curtis)

- Sacculus with a small process on ventral edge of basal opening, not reaching costa

R. orbiculata sp. n.

10. Tegumentary projections horned 11

- Tegumentary projections clubbed 13

11. Tegumentary projections narrow and long; socii small R. visenda (Kuznetsov)

- Tegumentary projections short; socii large 12

12. Neck of valva about $1 / 3$ of cucullus width; ventral angle of cucullus about $90^{\circ}$

\section{R. bucera sp.n.}

- Neck of valva as wide as cucullus width; ventral angle of cucullus acute-angled

R. blanditana (Kuznetsov)

13. Tegumentary projections bending inward

R. antrifera (Meyrick)

- Tegumentary projections straight, porrect 14

14. Tegumentary projections triangular, gradually narrowed to top; cucullus with a big process on outer margin

R. toshimai (Kawabe) 

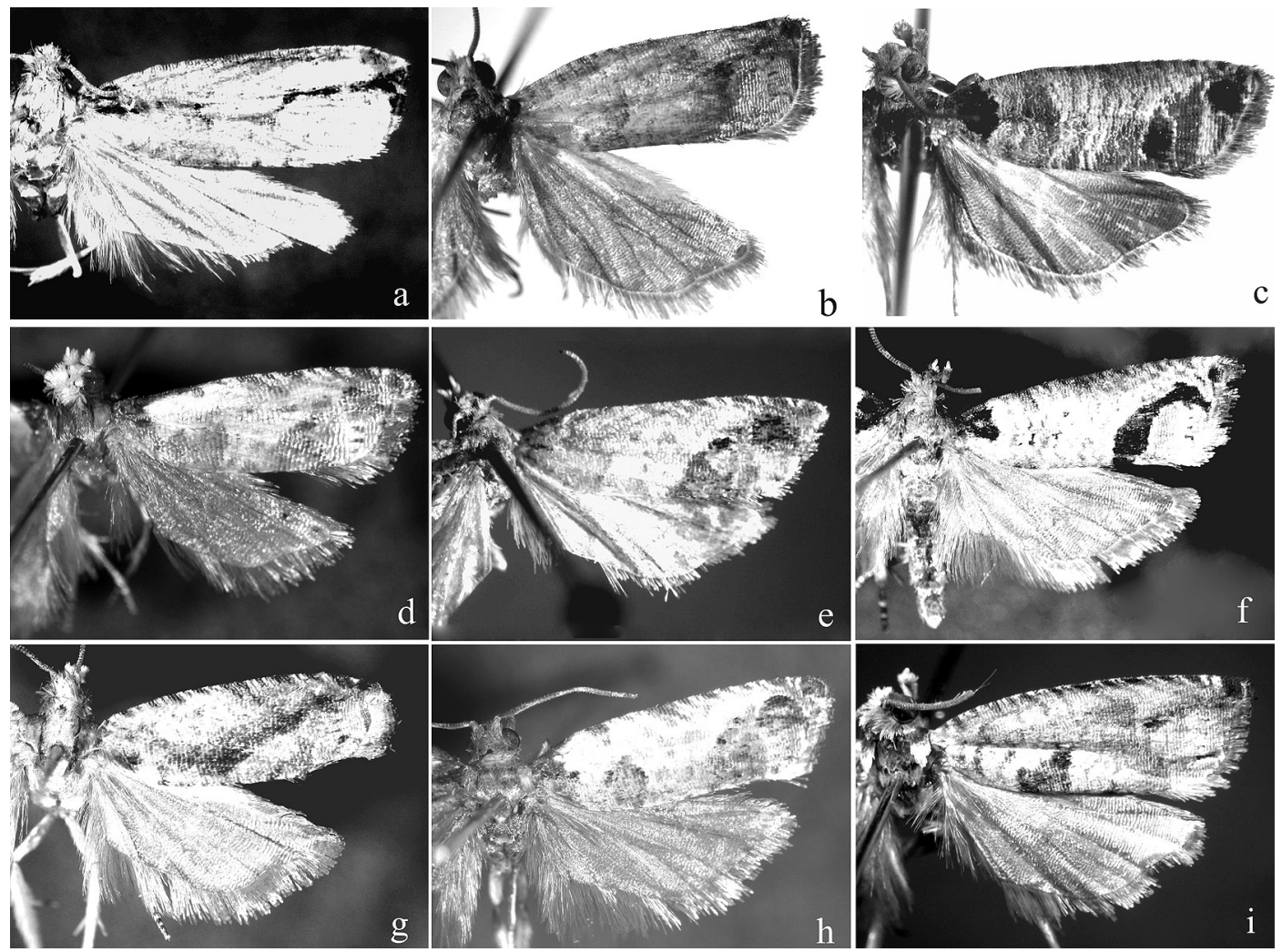

Fig. 1. Adults of Rhopobota spp. a. Rhopobota furcata sp. n., holotype $\delta^{\lambda}$. b. Rhopobota orbiculata sp. n., holotype $\delta^{\lambda}$. c. Rhopobota fanjingensis sp. n., holotype $\hat{\partial}$. d. Rhopobota floccosa sp. n., paratype $\partial^{\lambda}$. e. Rhopobota bucera sp. n., holotype $\hat{\jmath}$. f. Rhopobota antrifera (Meyrick), ô. g. Rhopobota bicolor Kawabe, q. h. Rhopobota blanditana (Kuznetsov), ô; i. Rhopobota eclipticodes (Meyrick), ô.

- Without integrated structures mentioned above

15. Neck of valva with thick spines on outer margin; cucullus about twice as long as its width

- Neck of valva without thick spines on outer margin; cucullus less than twice its width

R. floccosa sp. n.

16. Fore wing upperside with a bifurcate streak; ventral angle of cucullus protruded

R. furcata sp.n.

- Fore wing upperside without bifurcate streak; ventral angle of cucullus nearly $90^{\circ}$

R. fanjingensis sp. n.

\subsection{Rhopobota furcata sp. n. (Figs. 1a, 2a)}

Type material. Holotype $\delta^{\lambda}$ : China, Wenxian $\left(32.58^{\circ} \mathrm{N}, 104.41^{\circ} \mathrm{E}\right)$, Gansu Province, $2,000 \mathrm{~m}$ a.s.1., 5.VII.2001, Houhun Li and Xinpu Wang leg., genital slide no. ZAH03776. Paratype: 10 , same data as holotype.

Diagnosis. This species is similar to $R$. shikokuensis (Oku, 1971), but can be distinguished by: tegumentary projections shorter, blunt on termination and porrect, cucullus length less than twice its width and ventral angle protruded. In $R$. shikokuensis tegumentary projections slender, distally pointed and curved outward, cucullus length more than twice its width and ventral angle not protruded.

Description. Fore wing expanse 14.5-16.0 $\mathrm{mm}$. Vertex with erect grey scales, frons white. Antenna with scape grey and flagellum light brown. Labial palpus greyish brown, terminal segment porrect. Thorax grey; tegula with basal half brown and apical half grey. Fore wing upperside ground color grey, costa darker; costal strigulae indistinct; basal fascia brown, situated at 
basal $1 / 8$, not reaching dorsum; a brown streak running from anterior angle of cell, bifurcated near termen, one branch reaching apex, the other reaching nearly $1 / 2$ of termen; other patches and fasciae inconspicuous; cilia grey mixed with brown; underside dark grey, darker at costa. Hind wing upperside, underside and cilia grey. Prothoracic leg brown; mesothoracic leg grey, with tibiae and tarsi brown; metathoracic leg grey, with brown scales on tarsus.

Male genitalia (Fig. 2a). Tegumentary projections short clubbed, blunt on termination; socii large, triangular, haired. Valva broad at base, basal part wider than cucullus width, neck distinct, ventrally armed with thick spines to base of cucullus; cucullus nearly oblong, hairy, with marginal spines, rounded dorsally, ventral angle protruded. Aedeagus thick; cornuti numerous (deciduous) and undectected.

Female. Unknown.

Distribution. China (Gansu).

Etymology. The specific name is derived from the Latin furcatus = furcate, referring to the fore wing with a brown bifurcate streak.

\subsection{Rhopobota orbiculata sp. n. (Figs. 1b, 2b)}

Type material. Holotype $\hat{\jmath}$ : China, Kangxian $\left(33.20^{\circ} \mathrm{N}, 105.36^{\circ} \mathrm{E}\right)$, Gansu Province, $800 \mathrm{~m}$ a.s.1., 6.VI.1995, M. Aisiha'er leg., genital slide no. ZAH03729. Paratype: $1 \hat{\jmath}$, same data as holotype.

Diagnosis. This species is similar to $R$. ustomaculana (Curtis, 1831), but can be separated by fore wing upperside ground color grey, median fascia and ocellar area darker. Valva with a small pointed sclerotized process on distal edge of basal opening and sacculus with a weak lobe. In $R$. ustomaculana fore wing upperside brown, dorsum with a grey triangular patch, ocellus grey, valva with a large pointed sclerotized process on ventral edge of basal opening and sacculus without lobe.

Description. Fore wing expanse 16.0-19.0 $\mathrm{mm}$. Vertex with grey scales, frons white. Antenna with scape grey and flagellum brown. Labial palpus grey tinged brown, terminal segment slender, porrect. Thorax grey; tegula with basal half brown and apical half grey. Fore wing upperside ground color grey; two pairs of strigulae (pairs 3 and 4 )between base of the wing and the point where Sc meets costa; other five pairs (pairs 5 to 9) between $\mathrm{Sc}$ and $\mathrm{R}_{4}$; basal and subbasal fasciae forming indistinct basal patch, covering about $1 / 3$ of fore wing length; median fascia light brown, extending to proximal area of ocellus; ocellus nearly rounded; cilia greyish brown; underside dark grey except grey area of hind wing overlap posterior to $\mathrm{CuP}$, strigulae present at costa like that in upperside. Hind wing: upperside dark grey except grey area of fore wing overlap anterior to $\mathrm{Sc}+\mathrm{R}_{1}$; underside grey and cilia grey. Prothoracic leg brown; mesothoracic leg grey, with tibiae and tarsi brown; metathoracic leg grey, with brown scales on tarsus.

Male genitalia (Fig. 2b). Tegumentary projections large and long, sickle-like; socii broad, large finger-shaped, hairy. Valva broad, with a small pointed sclerotized process on distal ventral edge of big basal opening; sacculus with a weak lobe at base; cucullus slightly dilated, hairy, with three thick setae on ventral margin. Aedeagus elongate; cornuti numerous, spiculate.

Female. Unknown.

Distribution. China (Gansu).

Etymology. The specific name is derived from the Latin orbiculatus $=$ circular, in reference to the fore wing with a nearly rounded ocellar area.

\subsection{Rhopobota fanjingensis sp. $n$.} (Figs. 1c, 2c)

Type material. Holotype $\widehat{\jmath}$ : China, Mt. Fanjing $\left(27.55^{\circ} \mathrm{N}, 108.41^{\circ} \mathrm{E}\right)$, Guizhou Province, 2,100 $\mathrm{m}$ a.s.1., 30.VII.2001, Houhun Li and Xinpu Wang leg., genital slide no. ZAH03606. Paratypes: 3 $\widehat{\partial}$, same data as holotype, one slide no. ZAH03209.

Diagnosis. This species is similar to $R$. antrifera (Meyrick, 1935), but can be identified by the following characters: fore wing with a brown blotch anterior to ocellar area, tegumentary projections porrect and cucullus with ventral angle $90^{\circ}$ in the male genitalia. In $R$. antrifera ocellus circled with brown fascia above and inside, tegumentary projections bending inward and cucullus with ventral angle produced into a small process.

Description. Fore wing expanse $14.5 \mathrm{~mm}$. 
Fig. 2. Male genitalia of
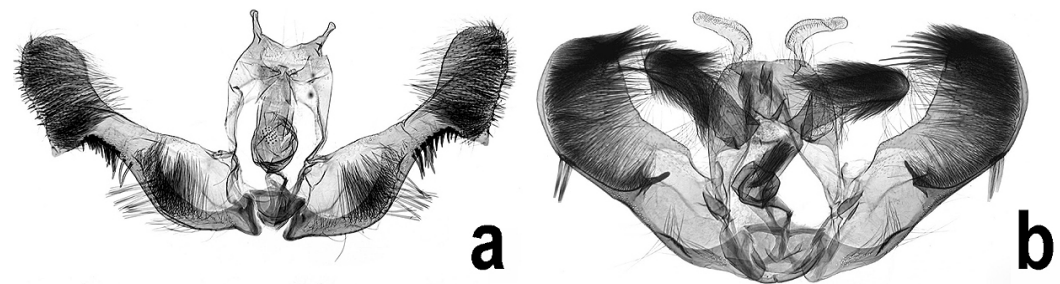

Rhopobota spp. a. Rhopobota furcata sp. n., holotype, slide no. ZAH03776. b. Rhopobota orbiculata sp. n., holotype, slide no. ZAH03729. c. Rhopobota fanjingensis sp. n., holotype, slide no. ZAH03606. d. Rhopobota floccosa sp. n., holotype, slide no. ZAH03430. e. Rhopobota bucera sp. n., holotype, slide no.

ZAH04091. f. Rhopobota antrifera (Meyrick), slide no. ZAH04093. g. Rhopobota bicolor Kawabe, slide no. ZAH03348. h. Rhopobota blanditana (Kuznetsov), slide no. ZAH03758.
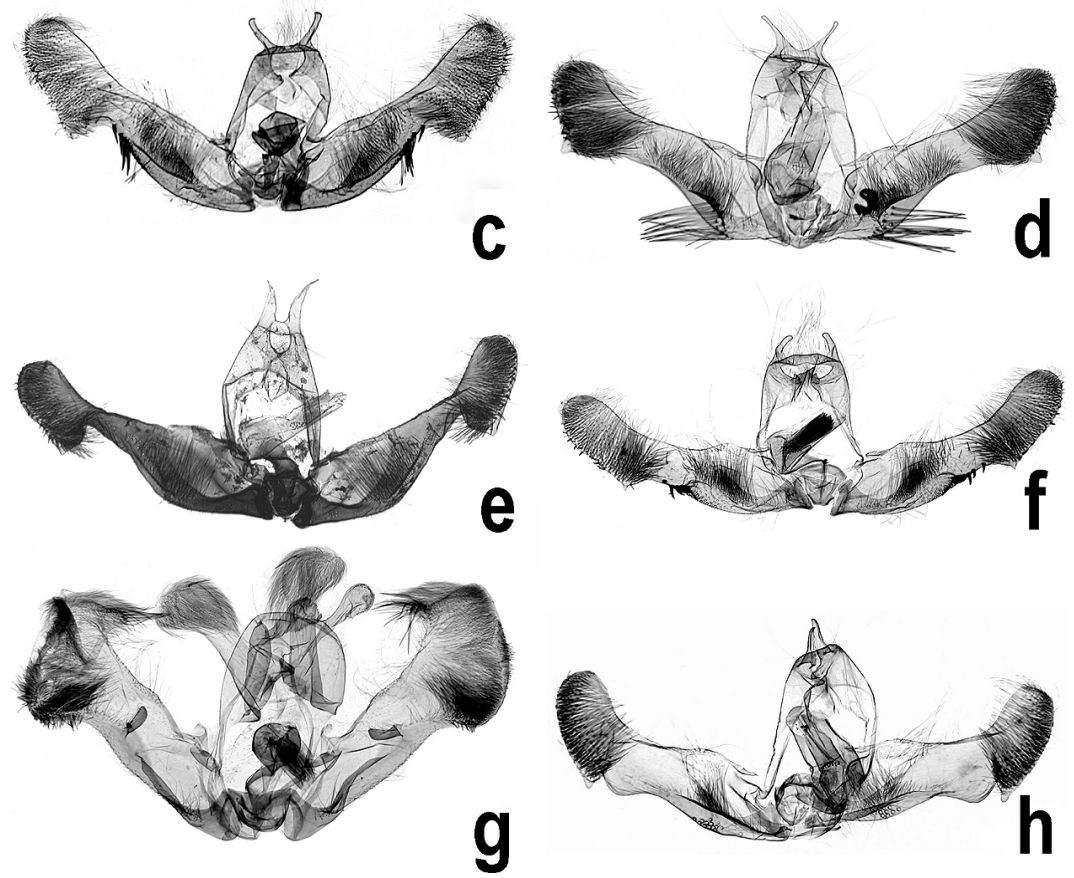

Vertex with greyish yellow scales, frons white. Antenna with scape grey and flagellum light brown. Labial palpus greyish brown, terminal segment porrect. Thorax and tegula brown. Fore wing upperside ground color greyish brown, covered with slender transverse grey streaks; costa with nine pairs of strigulae, the first four pairs indistinct, distributed between base and the point where Sc meets costa, two pairs of strigulae (5-6) between $\mathrm{Sc}$ and $\mathrm{R}_{1}$ points, other three pairs of strigulae (7, 8 and 9) distributed between veins $R_{1}$ and $R_{2}, R_{2}$ and $R_{3}, R_{3}$ and $R_{4}$ respectively; basal fascia brown, well developed; a narrow and long brown blotch situated on distal 2/3 of dorsum; ocellus grey, with a brown blotch above; cilia brown, mixed with grey on ocellus; underside brown except grey area of hind wing overlap posterior to $\mathrm{CuP}$. Hind wing upperside dark grey, except grey area of fore wing overlap anterior to
$\mathrm{Sc}+\mathrm{R}_{1}$, cilia grey; underside light brown. Prothoracic leg brown; mesothoracic leg grey, with tibia and tarsus brown; metathoracic leg grey, with brown scales on tarsus.

Male genitalia (Fig. 2c). Tegumentary projections clubbed, long, porrect; socii large, triangular, haired. Valva elongate, basal part as wide as cucullus, with thick spines on outer margin of neck; sacculus finely haired, with a drape situated below ventral edge of basal opening, ventral angle of sacculus indistinct; cucullus oblong, broad, hairy, with marginal spines, ventral angle nearly $90^{\circ}$. Aedeagus elongate; cornuti numerous, spiculate.

Female. Unknown.

Distribution. China (Guizhou).

Etymology. The specific name refers to the type locality. 


\subsection{Rhopobota floccosa sp. n. (Figs. 1d, 2d)}

Type material. Holotype $\hat{\sigma}^{\top}$ : China, Sangzhi County $\left(29.23^{\circ} \mathrm{N}, 110.11^{\circ} \mathrm{E}\right)$, Hunan Province, 1,250 m a.s.1., 12.VIII.2001, Houhun Li and Xinpu Wang leg., genital slide no. ZAH03430. Paratype: 1 ก, 13.VIII.2001, other same data as holotype.

Diagnosis. This species is similar to $R$. relicta (Kuznetsov, 1968), but can be differentiated from the latter by tegumentary projections slender, sacculus with a tuft of hairs situated below ventral edge of basal opening, cucullus with ventral angle protruded. In $R$. relicta tegumentary projections broad and short, sacculus without a tuft of hairs and cucullus with ventral angle blunt.

Description. Fore wing expanse $11.0 \mathrm{~mm}$. Head white, frons with erect scales. Antenna with scape white and flagellum brown. Labial palpus grey, terminal segment white. Thorax and tegula brown. Fore wing upperside ground color grey, brown on apex; costa with only a pair of strigulae between base and Sc distinct, other five pairs distributed between $\mathrm{Sc}$ and $\mathrm{R}_{4}$; basal fascia minute, brown; dorso-postbasal blotch dark grey right triangular; ocellus small, contained some brown longitudinal streaks, a large dark grey blotch located on the inner side of ocellus; cilia grey; underside dark grey. Hind wing upperside and cilia grey; underside grey. Prothoracic leg brown; mesothoracic leg grey, with tibia and tarsus brown; metathoracic leg grey, with brown scales on tarsus.

Male genitalia (Fig. 2d). Tegumentary projections slender, porrect, wider at base, gradually narrowed to middle; socii triangular, with a few hairs. Valva long, with a distinct neck; sacculus with some thick hairs, on ventral edge of basal opening situated a tuft of hairs; cucullus broad and short, hairy, with marginal spines, ventral angle protruded. Aedeagus stout; cornuti numerous and deciduous (undetected).

Female. Unknown.

Distribution. China (Hunan).

Etymology. The specific name is derived from the Latin floccosus = flocculent, in reference to sacculus with a tuft of hairs situated below ventral edge of basal opening in the male genitalia.

\subsection{Rhopobota bucera sp. n. (Figs. 1e, 2e)}

Type material. Holotype $\delta^{\top}$ : China, Yangling $\left(34.17^{\circ} \mathrm{N}, 108.40^{\circ} \mathrm{E}\right)$, Shaanxi Province, $450 \mathrm{~m}$ a.s.1., 24.V.1985, Houhun Li leg., genital slide no. ZAH04091.

Diagnosis. This species is similar to $R$. macrosepalana (Oku, 1971), but can be distinguished by the following characters of the male genitalia: tegumentary projections horned, ventral angle of the sacculus obtuse. While in $R$. macrosepalana tegumentary projections short clubbed, ventral angle of the sacculus indistinct.

Description. Fore wing expanse $12.5 \mathrm{~mm}$. Vertex grey mixed with greyish brown, frons white. Antenna with scape grey and flagellum light brown. Labial palpus greyish brown, terminal segment white. Thorax brown mixed with grey; tegula with basal $1 / 3$ brown and apical $2 / 3$ grey. Fore wing upperside ground color grey; costa with seven pairs of strigulae, the first two pairs between base and the point where Sc meets costa, other five pairs between $\mathrm{Sc}$ and $\mathrm{R}_{4}$; basal and subbasal fasciae forming basal patch, extending from $1 / 6$ of costa to $1 / 3$ of dorsum, protruded; ocellus silvery, circled with brown scales above and inside; cilia greyish brown; underside dark grey, with strigulae at costa like that on upperside. Hind wing upperside and cilia grey; underside grey. Prothoracic leg brown; mesothoracic leg grey, with tibia and tarsus brown; metathoracic leg grey, with brown scales on tarsus.

Male genitalia (Fig. 2e). Tegumentary projections large, horned, weakly sclerotized; socii with a few hairs. Valva narrow and long, with a slender neck; sacculus with long hairs, with a drape situated on posterior edge of basal opening, sacculus angle obtused; cucullus nearly oblong, hairy, with marginal spines, rounded dorsally, ventral angle $90^{\circ}$. Aedeagus elongate; cornuti numerous (deciduous).

Female. Unknown.

Distribution. China (Shaanxi).

Etymology. The specific name is derived from the Latin "bucerus" = horned, referring to the shape of the tegumentary projections in the male genitalia. 


\subsection{Rhopobota antrifera (Meyrick, 1935) (Figs. 1f, 2f)}

Eucosma antrifera Meyrick, 1935: 56; Clarke, 1958: 347.

Griselda antrifera (Meyrick) Kuznetsov, 1979: 83.

Rhopobota antrifera (Meyrick) Brown, 1983: 100; Kuznetsov, 2001: 419.

Material examined. 1 ô, China: Hefeng County, Hubei Province, 1,260 m a.s.1., 15.VII.1999, Houhun Li et al. leg.; 3 ふ઼ふ, Mt. Fanjing, Guizhou Province, 1,700 m a.s.l., 1.VI.2002, Xinpu Wang leg.

Male genitalia (Fig. 2f). As illustrated.

Distribution. China (Zhejiang, Hubei, Guizhou), Russia.

Remarks. The wing pattern and the male genitalia of this species are provided by Clarke (1958). The species is much similar to $R$. shikokuensis (Oku, 1971), but differs in tegumentary projections bending inward, ventral angle of cucullus protrudent and produced into a small process. In $R$. shikokuensis tegumentary projections bending outward, ventral angle of cucullus not protruding.

\subsection{Rhopobota bicolor Kawabe, 1989}

(Figs. 1g, 2g, 3a)

Rhopobota bicolor Kawabe, 1989: 62.

Material examined. 2 ๙ิ ô, China: Lichuan, Hubei Province, $700 \mathrm{~m}$ a.s.1., 28.VII.1999,

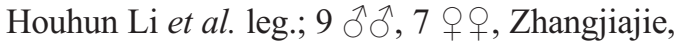
Hunan Province, $650 \mathrm{~m}$ a.s.1., 7-11.VIII. 2001, Houhun Li and Xinpu Wang leg.

Male genitalia (Fig. 2g). As illustrated.

Female genitalia (Fig. 3a). As illustrated.

Distribution. China (Hubei, Hunan, Taiwan), Japan, Thailand.

Remarks. Kawabe (1989) provided the photographs of adult, male and female genitalia of the species. This species is typically represented by ground color of fore wing bicolored, i.e. the anterior part blackish brown and the posterior part pale greyish brown.

\subsection{Rhopobota blanditana (Kuznetsov, 1988) (Figs. 1h, 2h)}

Griselda blanditana Kuznetsov, 1988: 622.

Griselda nielseni Kawabe, 1989: 58.

Rhopobota blanditana (Kuznetsov)

Kuznetsov, 1999: 343.

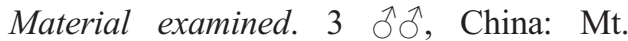
Fanjing, Guizhou Province, 1,300 m a.s.1., 23.VIII.2001, Houhun Li and Xinpu Wang leg.; 1 $\hat{\jmath}$, Baoxing County, Sichuan Province, 1,600 m a.s.1., 3.VIII.2004, Yingdang Ren leg.

Male genitalia (Fig. 2h). As illustrated.

Distribution. China (Sichuan, Guizhou, new record for China), Vietnam, Thailand.

Remarks. Kuznetsov (1999) transferred Griselda blanditana Kuznetsov to Rhopobota and synonymized Griselda nielseni Kawabe with this present species. This species is similar to Rhopobota antrifera (Meyrick) in appearance and genital characters, but can be easily distinguished by thorn-like tegumentary projections and sacculus angle obtused. In Rhopobota antrifera tegumentary projections are slender and bending inward, sacculus angle is indistinct.

\subsection{Rhopobota eclipticodes (Meyrick, 1935)} (Figs. 1i, 3b, 4a)

Acroclita eclipticodes Meyrick, 1935: 52.

Erinaea eclipticodes (Meyrick) Clarke, 1958: 343.

Rhopobota eclipticodes (Meyrick) Brown, 1979: 23.

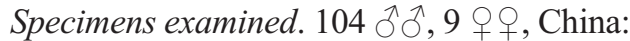
Mt. Tianmu, Zhejiang Province, 350-1,500 m

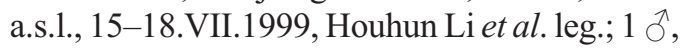
Wufeng County, Hubei Province, 1,100 m a.s.1., 11.VII.1999, Houhun Li et al. leg.; 1 ふै, Jiangkou County, Guizhou Province, 1,700 m a.s.1., 29.VII.2001, Houhun Li and Xinpu Wang leg.

Description. Male and female fore wing expanse 12.0-14.0 $\mathrm{mm}$. Vertex brown mixed with white. Antenna light fulvous. Labial palpus greyish brown; second segment apically white. Thorax greyish brown mixed with grey; tegula with basal half greyish brown and apical half grey. Fore wing upperside ground color grey; costa with nine pairs of strigulae, the first four pairs dis- 
tributed between base to the point $\mathrm{Sc}$ meets costa, other five pairs between $\mathrm{Sc}$ and $\mathrm{R}_{4}$; dorsum with a triangular greyish brown dorso-postbasal blotch; ocellus oval, grey, contained four longitudinal brown streaks; cilia grey, brown on apex; underside dark grey. Hind wing upperside and cilia grey; underside grey. Prothoracic and mesothoracic legs grey, with tibiae and tarsi brown; metathoracic leg grey.

Male genitalia (Fig. 4a). Tegumentary projections slender, long sickle-shaped, bending outward; socii finger-shaped, large, hairy. Valva elongate, with a large triangular process on posterior edge of basal opening; sacculus with a semicircular lobe; cucullus broad, hairy, with three or four thick setae (lost) ventrally. Aedeagus short; cornuti numerous, spiculate.

Female genitalia (Fig. 3b). As illustrated.

Distribution. China (Zhejiang, Hubei, Guizhou).

Remarks. This species was originally described based on the female specimen collected from Mt. Tianmu, Zhejiang Province. Clarke (1958) transferred Acroclita eclipticodes Meyrick to Erinaea and gave the photographs of wing pattern and female genitalia. During our study we found both sexes of the species from its type locality and other areas. This is the first description of the male.

\subsection{Rhopobota falcata Nasu, 1999}

(Figs. 5a, 4b)

Rhopobota falcata Nasu, 1999: 127.

Material examined. 2 ふึે, China: Shangsi County, Guangxi Province, $510 \mathrm{~m}$ a.s.1., 6.IV.2002, Shulian Hao and Huaijun Xue leg.

Male genitalia (Fig. 4b). As illustrated.

Distribution. China (Guangxi, new record for China), Japan.

Remarks. This species is similar to R. symbolias (Meyrick), but differs in neck of valva broad, angle of the sacculus indistinct; while in the latter species neck is thin and angle of the sacculus is obtuse.

\subsection{Rhopobota latipennis (Walsingham, 1900) (Figs. 4c, 5b)}

Ancylis latipennis Walsingham, 1900: 439.

Ancylis latipennis var. ussuriensis Caradja, 1916: 72.

Rhopobota latipennis (Walsingham) Issiki, 1957: 66; Kawabe 1982: 140; Liu \& Li 2002: 311.

Specimens examined. 1 o, China: Songxian, Henan Province, 1580 m, 24.VII.2002, Xinpu Wang leg.

Male genitalia (Fig. 4c). As illustrated.

Host plant. Padus racemosa (Rosaceae) (Liu \& Li 2002).

Distribution. China (Heilongjiang, Jiangxi, Henan), Japan, Russia (Far East).

Remarks. Kawabe (1982) provided the adult photograph. Liu \& Li (2002) recorded this species from Heilongjiang Province and gave the illustrations of adults and genitalia. It resembles Rhopobota naevana (Hübner). The difference between them is remarked in the latter species.

\subsection{Rhopobota naevana (Hübner, 1817)} (Figs. 3c, 4d, 5c)

Tortrix naevana (Hübner, 1817): pl. 41, fig. 261. Tortrix unipunctana (Haworth, 1811): 454. [preoccupied]

Lithographia geminana Stephens, 1852: 99.

Sciaphila luciferana Walker, 1863: 342.

Anchylopera vacciniana Packard, 1869: 338.

Epinotia ilicifoliana Kearfott, 1907: 58.

Acroclita microrryncha Meyrick, 1931: 127.

Rhopobota naevana (Hübner) Lederer, 1859:

367; Bradley et al. 1979: 137; Kawabe 1982: 140;

Razowski 1989: 253; Razowski 2001: 72;

Kuznetsov 2001: 413; Liu \& Li 2002: 312.

Material examined. 55 ิิ ô, 21 우, China: Heshan, Guangdong Province, 9.-10.X.2001 and

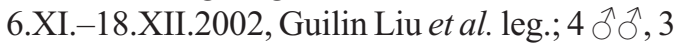
우, Xilinhot, Inner Mongolia, 1,030 m a.s.1., 9.10.VIII.1997, Houhun Li leg.; 2 ふึ đૈ, 2 우, Mt. Fanjing, Guizhou Province, 1300-2,100 m a.s.1., 31.VII.-2.VIII.2001, coll. Houhun Li and Xinpu Wang leg.; 1 J, 1 O, Yuzhong County, Gansu Province, 2,130 m a.s.1., 2.VIII.1993, Houhun Li leg.; 6 우, Jixian, Tianjin, 500-550 m a.s.1., 


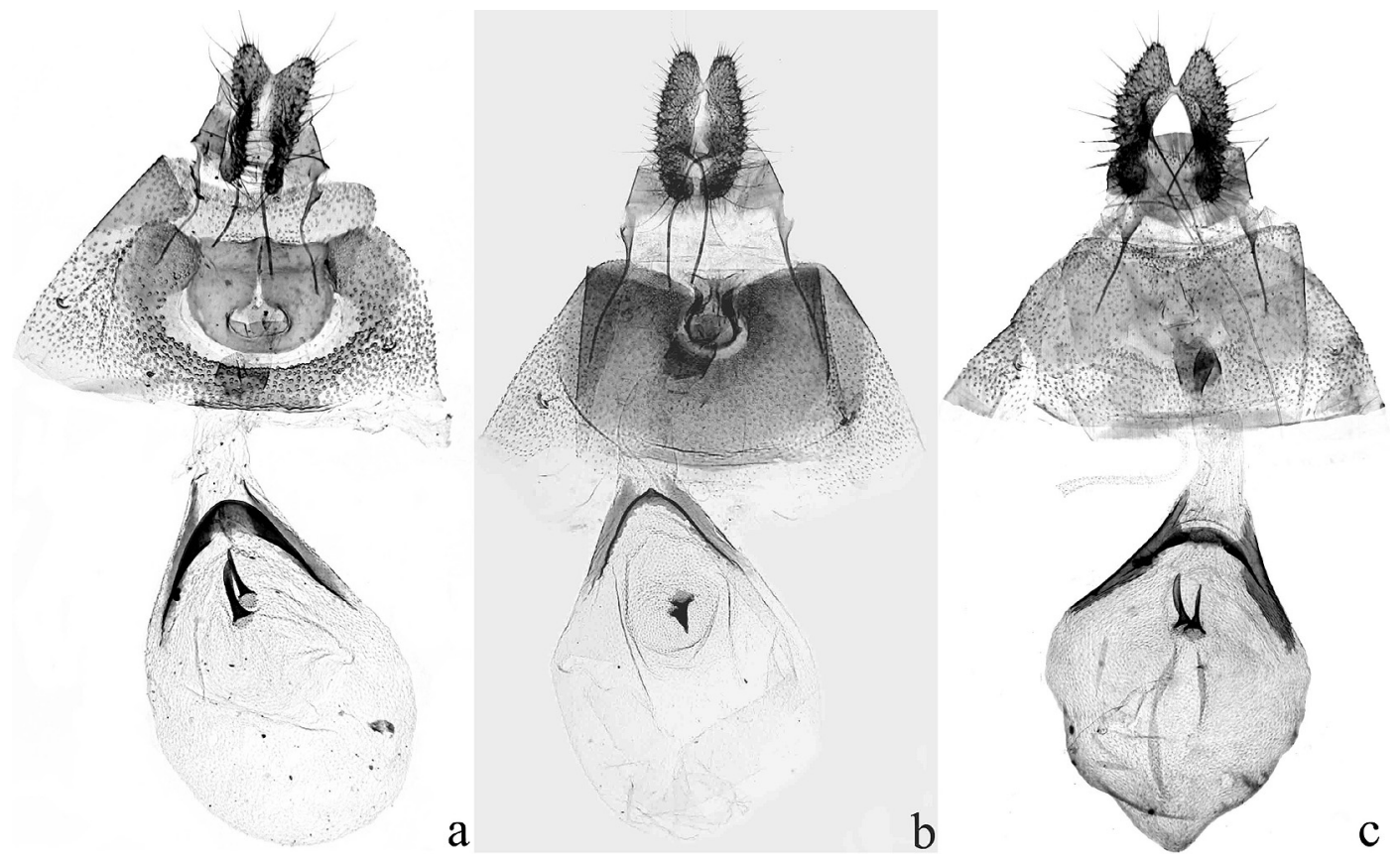

Fig. 3. Female genitalia of Rhopobota spp. a. Rhopobota bicolor Kawabe, slide no. ZAH04006. b. Rhopobota eclipticodes (Meyrick), slide no. ZAH04178. c. Rhopobota naevana (Hübner), slide no. ZAH03664.

23.VI.-9.IX.2001, Houhun Li et al. leg.; 3 ふึત, Guiyang, Guizhou Province, 1,100 m a.s.1., 25.VII. 2001, Houhun Li and Xinpu Wang leg.; 15 ふ઼े, 3 우, Weishan County, Yunnan Province, 2,200 m a.s.1. 20.VII.2001, Houhun Li and Xinpu Wang leg.; 1 q, Zhangjiajie, Hunan Province, $650 \mathrm{~m}$ a.s.1., 7.VIII.2001, HouHun Li and

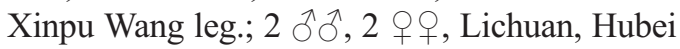
Province, 700 m a.s.1., 29.VII.1999, Houhun Li et al. leg.; 1 ô, 3 우, Mt. Tianmu, 350-1,500 m a.s.1., 15.-18.VIII.1999, Houhun Li et al. leg.; 1 q, Yuxian, Hebei Province, 1,200 m a.s.l., 22.VII.2000, Yanli Du and Shulian Hao leg.; 2 ${ }^{\circ}$, Jingxing County, Hebei Province, 1,200 m a.s.1., 23 \& 26.VII.2000, Haili Yu et al. leg.; 3 $\hat{\jmath} \hat{o}$, Lijiang, Yunnan Province, 2,650 m a.s.1., 18.VII.2001, Houhun Li and Xinpu Wang leg.; 2

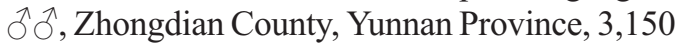
$\mathrm{m}$ a.s.1., 14.VII.2001, Houhun Li and Xinpu Wang leg.; 1 ô, Wufeng County, Hubei Province, 1,000 m a.s.1., 10.VII.1999, Houhun Li et al. leg.; 1 q, Hefeng County, Hubei Province, 1,260 m a.s.l., 15.VII.1999, Houhun Li et al. leg.; 4 $\widehat{\partial}, 1$ 9 , Jianyang County, Sichuan Province, 350-400 m a.s.1., 1.-4.V.1994, Jin Zhou leg.; 1 ô, Xishui County, Guizhou Province, $500 \mathrm{~m}$ a.s.1.,
31.V.2000, Yanli Du leg.; 1 ふ, 1 \&, Xinyang County, Henan Province, 700 m a.s.1., 9.VII.1997 and 13.VII.2001, Houhun Li and Dandan Zhang

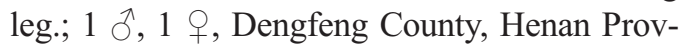
ince, $700 \mathrm{~m}$ a.s.1., 15.VII.2002, Xinpu Wang leg.; 1 q , Luoyang, Henan Province, 1,560 m a.s.1., 23.VII.2001, Dandan Zhang leg.; 1 , Jiangkou County, Guizhou Province, $600 \mathrm{~m}$ a.s.1., 28.VII.2001, Houhun Li and Xinpu Wang leg.; 2

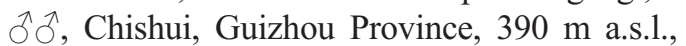
29.V.2000, Yanli Du leg.; 47 $\widehat{\jmath}, 7$ 우, Yuexi County, Anhui Province, 2.-29.VIII.1995 and 25.VII.1996, Xiangfu $\mathrm{Hu}$ leg.; 1 ふै, Bowo County, Xizang (Tibet) Autonomous Region, 2,950 $\mathrm{m}$ a.s.1., 9.VIII.2003, Xinpu Wang and Huaijun Xue leg.; 2 ふึે, 2 qㅇ, Shennongjia, Hubei Province, 1,100 m a.s.1., 17.-19.VII.2003, Shulian Hao leg.; $1 \hat{\jmath}$, Dehua County, Fujian Province, $850 \mathrm{~m}$ a.s.1., 15.IX.2002, Xinpu Wang leg.; 1 q, Shangzhou, Shaanxi Province, $720 \mathrm{~m}$ a.s.1., 26.V.1994, Jin Zhou leg.

Host plants. Fraxinus mandshurica (Oleaceae), Vaccinium vitis-idaea (Ericaceae), Malus spectabilis, Pyrus serotina, Crataegus pinnatifida, Armeniaca vulgaris, Prunus mume, Sorbus (Rosaceae), Rhamnus davurica (Rhamnaceae), 

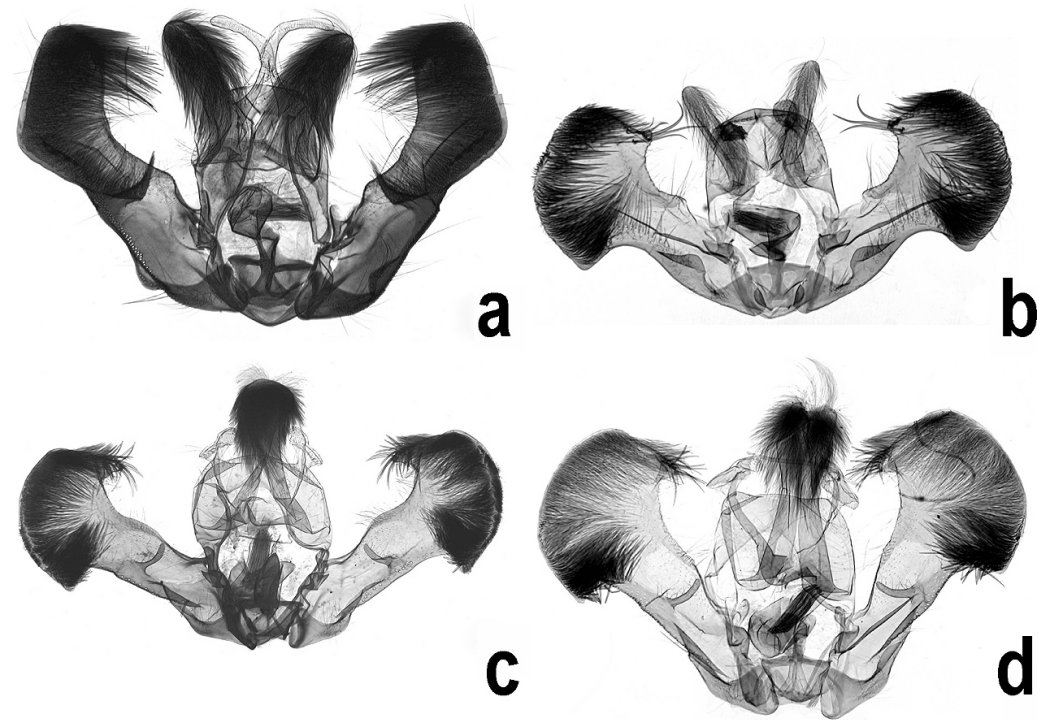

Fig. 4. Male genitalia of Rhopobota spp. a. Rho-
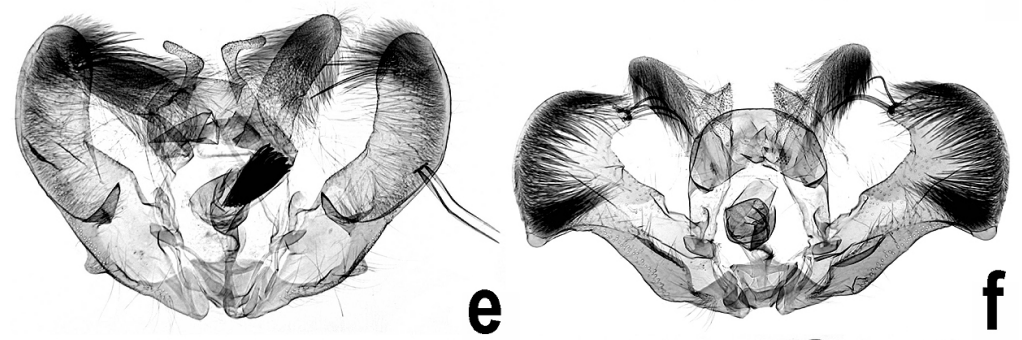
pobota eclipticodes (Meyrick), slide no. ZAH04177. b. Rhopobota falcata Nasu, slide no. ZAH03558. c. Rhopobota latipennis (Walsingham), slide no. ZAH04003. d. Rhopobota naevana (Hübner), slide no. ZAH03665. e. Rhopobota okui Nasu, slide no.
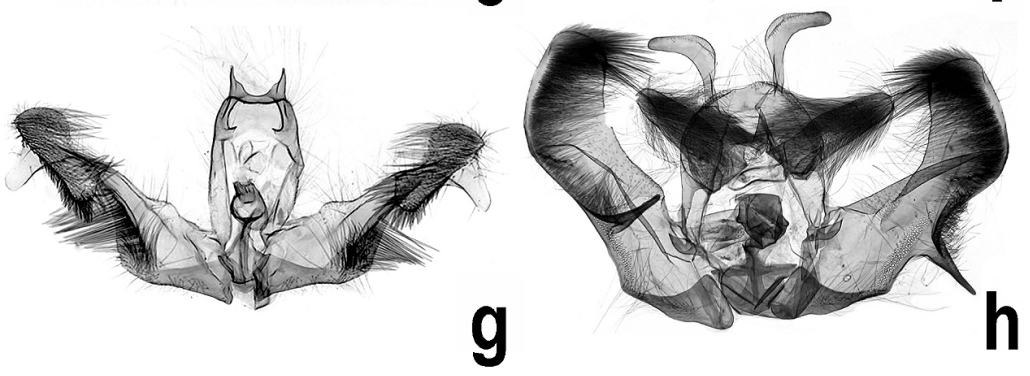
ZAH03817. f. Rhopobota symbolias (Meyrick), slide no. ZAH03748. g. Rhopobota toshimai (Kawabe), holotype, slide no. 4041. h. Rhopobota ustomaculana (Curtis), slide no. ZAH03433.

Ilex integra (Aquifoliceae) (Kuznetsov 2001, Liu \& Li 2002).

Male genitalia (Fig. 4d). As illustrated.

Female genitalia (Fig. 3c). As illustrated.

Distribution. China (Tianjin, Hebei, Inner Mongolia, Liaoning, Heilongjiang, Zhejiang, Anhui, Fujian, Jiangxi, Henan, Hubei, Hunan, Guangdong, Sichuan, Guizhou, Yunnan, Tibet, Shaanxi, Gansu, Taiwan), Mongolia, Korea, Japan, India, Sri Lanka, Russia, Europe.

Remarks. This species is similar to Rhopobota latipennis (Walsingham, 1900), but can be identified by the presence of a blue blotch on costa of the hind wing upperside. In Rhopobota latipennis this blue blotch is not present.

\subsection{Rhopobota okui Nasu, 2000}

(Figs. 4e, 5d)

Rhopobota okui Nasu, 2000: 21.

Material examined. 1 ô, China: Xixia County, Henan Province, $890 \mathrm{~m}$ a.s.1., 19.VII.1998, Houhun Li leg.; 1 ô, Daozhen County, Guizhou Province, 1,350 m a.s.1.,

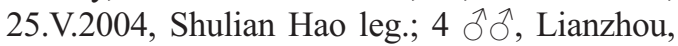
Guangdong Province, $650 \mathrm{~m}$ a.s.1., 22.25.VI.2004, Dandan Zhang leg.; 3 ふึ่, 1 ㅇ, 
Fig. 5. Adults of Rhopobota spp. a. Rhopobota falcata Nasu, ô. b. Rhopobota latipennis (Walsingham), o. c. Rhopobota naevana (Hübner), o. d. Rhopobota okui Nasu, ô. e. Rhopobota symbolias (Meyrick), 今. f. Rhopobota toshimai (Kawabe), ô.g. Rhopobota ustomaculana (Curtis), ô. h. Rhopobota visenda (Kuznetsov), holotype ${ }^{\dagger}$.
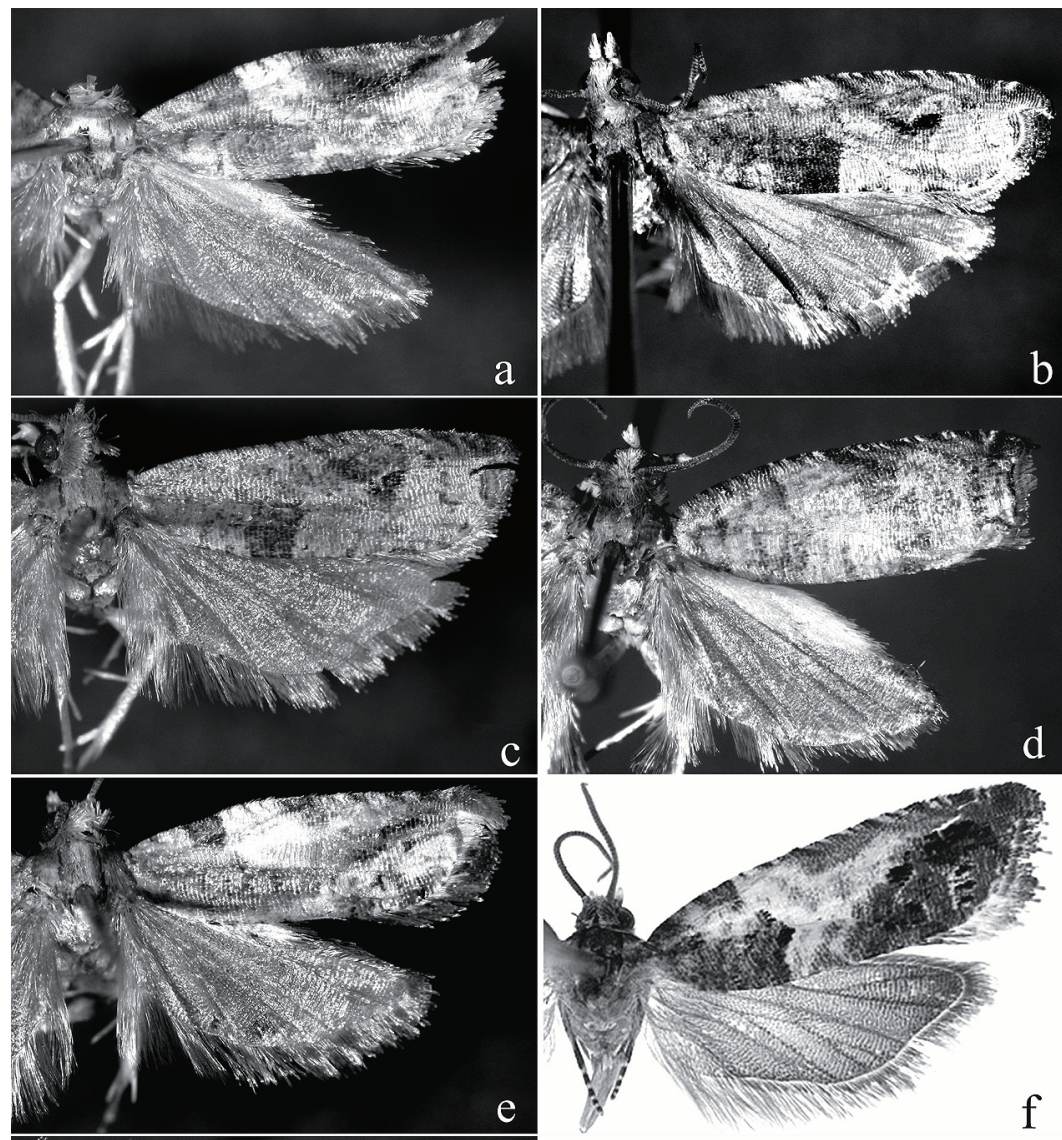

d
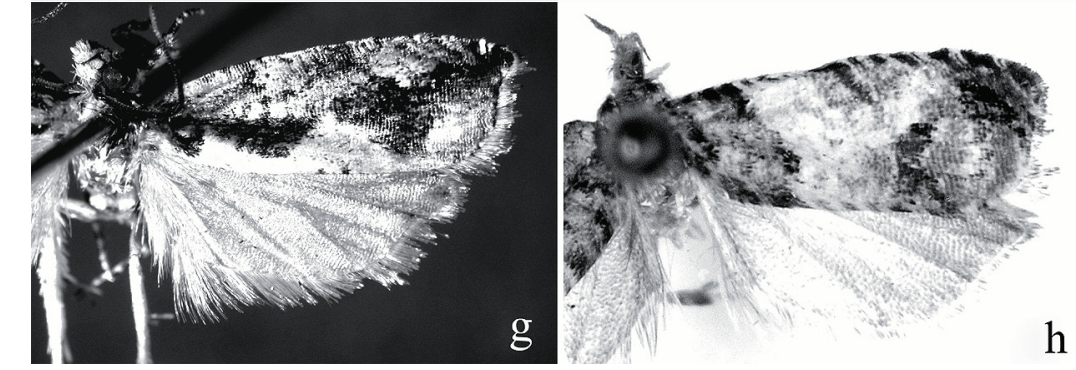

Mabian County, Sichuan Province, 1,200 m a.s.1., 22.VII.2004, Yingdang Ren leg.

Male genitalia (Fig. 4e). As illustrated.

Distribution. China (Henan, Guangdong, Sichuan, Guizhou, new record for China), Japan.

Remarks. This species is allied to $R$. eclipticodes (Meyrick, 1935), but can be separated by cucullus rounded dorsally, with two long setae on outer margin. In $R$. eclipticodes cucullus straight dorsally, with three or four long setae on outer margin.

\subsection{Rhopobota symbolias (Meyrick, 1912)}

(Figs. 4f, 5e)

Acroclita symbolias Meyrick, 1912: 857; Clarke 1958: 283.

Eumarissa symbolias (Meyrick) Clarke, 1976: 36.

Rhopobota symbolias (Meyrick) Diakonoff, 1982: 54; Brown 1983: 102; Nasu 1999: 128.

Material examined. 1 , , China: Shangsi County, Guangxi Province, $510 \mathrm{~m}$ a.s.1., 6.IV.2002, Shulian Hao and Huaijun Xue leg.; 4 


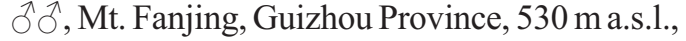
2.-3.VI.2002, Xinpu Wang leg.; 1 ふ, Mt. Fanjing, Guizhou Province, 1,300 m a.s.l., 1.VIII.2001, Houhun Li and Xinpu Wang leg.; 2 ồ, Lichuan, Hubei Province, $700 \mathrm{~m}$ a.s.1., 30.VII.1999, Houhun Li et al. leg.; 1 ふૈ, Zhangjiajie, Hunan Province, 7.VIII.2001, Houhun Li and Xinpu Wang leg.

Male genitalia (Fig. 4f). As illustrated.

Distribution. China (Hubei, Hunan, Guangxi,

Guizhou, new record for China), India.

Remarks. This species is closely related to Rhopobota falcata Nasu. The characters to separate them from each other are stated in the remarks of the latter species.

\subsection{Rhopobota toshimai (Kawabe, 1978)} (Figs. 4g, 5f)

Griselda toshimai Kawabe, 1978: 186.

Epinotia toshimai (Kawabe) Kawabe, Komai

\& Razowski 1992: 107.

Rhopobota toshimai (Kawabe) Brown, 1983:

104; Kuznetsov 2001: 419.

Type material. Holotype đ̊: Japan, ShikokuOkushioiri, Kagawa Pref., 15.VII.1972, T. Toshima leg., deposited in USNM and examined through the photographs of the adult from Taiwan and the genitalia of the holotype (USNM).

Male genitalia (Fig. 4g). As illustrated.

Distribution. China (Taiwan), Japan.

\subsection{Rhopobota ustomaculana (Curtis, 1831)} (Figs. 4h, 5g)

Steganoptycha ustomaculana Curtis, 1831: 8.

Steganoptycha dorsivittana Herrich-Sch fer, 1851: 280 .

Semasia ustomaculana (Curtis) Kennel, 1916: 500.

Rhopobota ustomaculana (Curtis) Pierce \& Metcalfe, 1922: 74; Kawabe 1970: 203; Bradley et al. 1979: 136; Kawabe 1982: 140; Razowski 1987: 157; Razowski 1989: 253; Razowski 2001: 72; Kuznetsov 2001: 413; Liu \& Li 2002: 313. Material examined. 3 ภิ $\hat{\jmath}$, China: Mt. Fanjing, Guizhou Province, 2,100 m a.s.1., 30.31.VII.2001, Houhun Li and Xinpu Wang leg.; 1 ô, Jiangkou County, Guizhou Province, 1,700 m a.s.1., 29.VII.2001, Houhun Li and Xinpu Wang leg.

Male genitalia (Fig. 4h). As illustrated.

Host plants. Citrus reticulata (Rutaceae), Vaccinium vitis-idaea (Ericaceae) (Kuznetsov 2001, Liu \& Li 2002).

Distribution. China (Anhui, Jiangxi, Hunan, Sichuan, Guizhou, Tibet), Japan, Russia (Far East), Europe.

Remarks. This species is characterized by boot-shaped tegumentary projections and large finger-shaped socii. Cucullus is slightly broader than basal part of valva and sacculus has a large process on ventral edge of basal opening.

\subsection{Rhopobota visenda (Kuznetsov, 1973) (Fig. 5h)}

Griselda visenda Kuznetsov, 1973: 682.

Rhopobota visenda (Kuznetsov) Brown, 1983: 105; Kuznetsov, 2001: 413.

Type material. Holotype $\widehat{\sigma}$ (no. 177102): China, Tapaishan im Tsinling, Sued-Shensi, 20.VI.1935, H. Höne leg., genitalia are preserved in tube (no. 186051), deposited in MGAB. Allotype $q$ (no. 177103), China: Tapaishan im Tsinling, Sued-Shensi, 22.VI.1935, H. Höne leg., genitalia are preserved in tube (no. 186052), deposited in MGAB. In this study, the types were examined through the photographs of adults.

Distribution. China (Shaanxi).

Acknowledgments. We wish to thank Dr. Yoshitsugu Nasu (Osaka Prefectural Agricultural, Forestry Research Center, Osaka, Japan) for his kind advice and assistance in references. We also acknowledge the assistance, with references received, from Prof. Dr. Richard L. Brown (Mississippi Entomological Museum, Department of Entomology, Mississippi State University, USA) and Mr. Nantasak Pinkaew (Department of Entomology, Kasetsart University, Bangkok, Thailand). We also thank Dr. John W. Brown (System Entomology Laboratory, USDA, Smithsonian Institution, National Museum of National History, Washington, D. C., USA) and Dr. Mihai Stanescu ("Grigore Antipa" National Museum of Natural History, Bucuresti, Romania) for transmitting photographs of $R$. toshimai (Kawabe) and $R$. visenda (Kuznetsov) and allowing us to use these photographs in the present paper. The research was supported by the National Natural Science Foundation of China for the Special Program. 


\section{References}

Brown, R. L. 1979: Nomenclatorial changes in Eucosmini (Tortricidae). - Journal of the Lepidopterists' Society 33(1): 21-28.

Brown, R. L. 1983: Taxonomic and morphological investigations of Olethreutinae: Rhopobota, Griselda, Melissopus and Cydia (Lepidoptera: Tortricidae). Entomography 2: 97-120.

Caradja, A. 1916: Beitrag zur Kenntnis der Geographischen Verbreitung der Pyraliden und Tortriciden des Europäischen Faunengebietes, nebst Beschreibung neurer Formen. - Dt. Ent. Z. Iris 30: 1-88.

Clarke, J. F. G. 1958: Catalogue of the Type Specimens of Microlepidoptera in the British Museum (Natural History) described by Edward Meyrick. Trustees of the British Museum 3: 1-600.

Clarke, J. F. G. 1976: Microlepidoptera: Tortricoidea. Insects of Micronesia 9(1): 1-144.

Curtis, J. 1824-1840: British entomology; being illustrations and descriptions of the genera of insects found in Great Britain and Ireland containing colorued figures from nature. London. 769 pls. in 16parts in 8 vols.

Diakonoff, A. 1982: On a collection of some families of Microlepidopera from Sri Lanka (Ceylon). Zool. Verh. 193: 1-124.

Haworth, A. H. 1811: Lepidoptera Britannica 3. - London. Pp. 377-512.

Heinrich, C. 1923: Revision of the North American Moths of the Subfamily Eucosminae of the Family Olethreutidae. Bull. U. S. Nat. Mus. Washington D. C. 123: 1298.

Herrich-Schäffer, G. A. W. 1851: Systematische Bearbeitung der Schmetterlinge von Europa. - Index Universalis Specierum \& Generum 4: 1-288.

Hübner, J. 1817: Sammlung Europäischer Schmetterlinge. - Augsburg. Part VII, Tortrices, Pls. 57-124.

Issiki, S. 1957: Eucosmidae. In: T. Esaki et al. (eds.), Icones Heterocerorum Japonicorum in Coloribus Naturalibus 1: 53-75.

Kawabe, A. 1978: Descriptions of three new genera and fourteen new species of the subfamily Olethreutinae from Japan. Tinea 10(19): 173-191.

Kawabe, A. 1982: Tortricidae. In: H. Inoue et al. (eds.), Moths of Japan 1: 1-955, 2: 1-552.

Kawabe, A. 1989: Records and descriptions of the subfamily Olethreutinae (Lepidoptera: Tortricidae) from Thailand. Microlepidoptera of Thailand 2: 23-82.

Kawabe, A., Komai, F. \& Razowski, J. 1992: Tortricidae. In: Heppner, J. B. \& Inoue, H. (eds.), Checklist. Lepidoptera of Taiwan 1(2): 276 pp.

Kearfott, W. D. 1907: New North American Tortricidae. Trans. Am. Ent. Soc. 33: 1-98.

Kennel, J. 1916: Die Palaearktischen Tortriciden. Schweizerbartsche Verlagsbuchhandlung, Stuttgart, 397-546.

Kuznetsov, V. I. 1973: Descriptions of new East Asian leafroller moths of the subfamily Olethreutinae (Lepidoptera, Tortricidae). Entomol. Obozr. 52: 682-699.
Kuznetsov, V. I. 1979: New species of leafrollers (Lepidoptera, Tortricidae) from the Far East. Trudy Zool. Inst. Leningr. 81: 76-86.

Kuznetsov, V. I. 1988: New species of tortricid moths of the subfamily Olethreutinae (Lepidoptera, Tortricidae) of the fauna of North Vietnam. Entomol. Obozr. 67(3): 615-631.

Kuznetsov, V. I. 1999: Annotated list of Tortricidae recorded from Vietnam (Lepidoptera). Zoosystematica Rossica 8(2): 337-348.

Kuznetsov, V. I. 2001: Tortricoidea. In: Ler, P. A. (ed.), Key to the Insects of Russian Far East. Vol. V. Trichoptera and Lepidoptera. Pt. 3. Vladivostok Dal'nauka, $621 \mathrm{pp}$.

Lederer, J. 1859: Classification der europäischen Tortriciden. — Wien. Ent. Mschr. 3: 366-389.

Li, H. H. \& Zheng, Z. M. 1996: Methods and techniques of specimens of Microlepidoptera. Journal of Shaanxi Normal University (Natural Science Edition) 24(3): 63-70.

Liu, Y. Q. \& Li, G. W. 2002: Fauna Sinica, Insecta, Vol. 27, Lepidoptera, Tortricidae. - Science Press, Beijing. $463 \mathrm{pp}$.

Meyrick, E. 1907: Descriptions of Indian Micro-lepidoptera. - J. Bombay Nat. Hist. Soc. 18: 137-160.

Meyrick, E. 1912: Descriptions of Indian Micro-lepidoptera. - J. Bombay Nat. Hist. Soc. 21: 852-877.

Meyrick, E. 1931: Exotic Microlepidopera 4: 33-192.

Meyrick, E. 1935: Materialien zu einer Microlepidoptera Fauna der Chinesischen Provinzen Kiangsu, Chekiang und Hunan. - R. Friedlander \& Sohn, Berlin. 96 pp. +3 pls.

Nasu, Y. 1999: Description of Rhopobota falcata sp. n. from Japan, with notes on $R$. symbolias (Meyrick) (Lepidoptera: Tortricidae). — Entomological Science 2(1): $127-130$.

Nasu, Y. 2000: One new and three newly recorded olethreutine moths (Lepidoptera, Tortricidae) from Japan. - Trans. Lepid. Soc. Japan 51(1): 19-28.

Oku, T. 1971: The Japanese species of the genus Griselda Heinrich, with descriptions of three new species (Lepidoptera: Tortricidae). — Konty 39: 352-358.

Packard, A. S. 1869: Guide to the study of insects. Naturalist Book agency, Salen, Massachusetts 6: 702 pp.

Pierce, F. N. \& Metcalfe, J. W. 1922: The genitalia of the group Tortricidae of the Lepidoptera of the British Islands. - Oundle 22: 101 pp. +34 pls.

Razowski, J. 1963: Tortricoidea (Lepidoptera) from Iran. - Acta Zool. Cracov. 8: 251-277.

Razowski, J. 1987: Lepidoptera of Poland. Part 7: Supplement and Eucosmini. - Monografie Fauny Polski 15: $1-268$.

Razowski, J. 1989: The genera of Tortricidae (Lepidoptera). Part II: Palaearctic Olethreutinae. - Acta. Zool. Cracov. 32(7): 107-328.

Razowski, J. 1995: Some Tortricidae from the Arabian Peninsula, with description of one new genus and four new species. — SHILAP Revta. Lepid. 29(90): 129139.

Razowski, J. 1999a: Catalogue of the species of Tortri- 
cidae. Part V: Palaearctic Eucosmina and Enarmoniina (Insecta: Lepidoptera). - SHILAP Revta. Lepid. 27(108): 437-506.

Razowski, J. 1999b: Discovery of Rhopobota Lederer, 1859 (Lepidoptera: Tortricidae) in the Neotropical region, with description of four new species. - Acta Zool. Cracov. 42(2): 349-353.

Razowski, J. 2001: Die Tortriciden (Lepidoptera, Tortricidae) Mitteleuropas. - Bestimmung Verbreitung Flugstandort Lebensweise der Raupen. Slovakia. 319

Stephens, J. R. 1852: List of the specimens of British ani- mals in the collection of the British Museum. Part 10. - Lepidoptera (continued). London. 120 pp.

Walker, F. 1863: List of the specimens of Lepidopterous insects in the collection of the British Museum, 28. British Museum (Nat. Hist.), London, 562 pp.

Walsingham, T. 1900: Asiatic Tortricidae. - Ann. Mag. Nat. Hist. (7) 6: 429-448.

Zhang, A. H. \& Li, H. H. 2004: A systematic study on the genus Nuntiella Kuznetsov (Lepidoptera: Tortricidae: Olethreutinae). — Acta Entomologica Sinica 47(4): 485-489. 